\title{
Сучасний стан популяції західного кукурудзяного жука Diabrotica virgifera virgifera (Coleoptera: Chrysomelidae) на території Волинської області
}

\section{Катерина Сухомлін ${ }^{1}$, Віталій Коширець ${ }^{2}$, Марія Зінченко ${ }^{1}$, Олександр Зінченко Юрій Білецький ${ }^{1}$}

${ }^{1}$ Східноєвропейський національний університет імені Лесі Українки, м. Луцьк, Україна

${ }^{2}$ ДУ «Волинська обласна фітосанітарна лабораторія», м. Луцьк, Україна

Адреса для листування: suhomlinkb@gmail.com

Отримано: 15.01.19; прийнято до друку: 18.02.19; опубліковано: 28.06.19

Резюме. Diabrotica virgifera virgifera - шкідник кукурудзи віднесений до карантинних об'єктів у Європі. Тому стан популяції західного кукурудзяного жука потребує постійного моніторингу й контролю чисельності та поширення. Проаналізовано результати проведених обстежень чисельності й поширення у 2017-2018 pр. на території Волинської області за даними ДУ «Волинська обласна фітосанітарна лабораторія». Моніторинг проводили методом маршрутних обстежень і за допомогою синтетичних статевих феромонів у посівах кукурудзи. Осередки захворювання виявляли завдяки наземно-візуальному обстеженню посадок кукурудзи, зокрема огляду кореневої системи та листкової поверхні ослаблених рослин кукурудзи. Для аналізу фітосанітарного ризику західного кукурудзяного жука здійснено розрахунок середньозважених показників вірогідності проникнення, акліматизації, потенційної економічної шкодочинності, вірогідність інтродукції та потенційних утрат. У Волинській області цей карантинний організм уперше простежено у 2017 р. Із того часу він збільшує площі ураження. Осередки шкідника зареєстровано в 10 районах, 11 населених пунктах на площі 406,238 га. 3'ясовано, що найбільші площі зараження (50-80 га) відзначено в Луцькому, Іваничівському, Ратнівському й Ковельському районах. Не зареєстровано осередків у Шацькому, Любомльському, Камінь-Каширському, Маневицькому, Ківерцівському, Рожищенському районах. Найвищий рівень ураження - у Луцькому районі. Проведений кількісний аналіз можливості акліматизації й поширення західного кукурудзяного жука показав, що шкідник належить до карантинних організмів і потребує застосування всіх фітосанітарних заходів щодо стримування й обмеження його поширення територією Волинської області. Установлено, що в межах області кліматичні умови та достатня кормова база сприйнятливі для розвитку D. virgifera virgifera, тому шкідник буде не лише виживати, а й збільшувати чисельність. Відсутність природних бар'єрів, які б обмежували поширення, сприяє розширенню ареалу.

Ключові слова: динаміка чисельності поширення, кількісний аналіз, вірогідність проникнення, вірогідність акліматизації, потенційна економічна шкодочинність, вірогідність інтродукції, потенційні втрати.

\section{The Current State of the Western Corn Rootworm Diabrotica Virgifera Virgifera (Coleoptera: Chrysomelidae) Population in the Volyn Region}

\section{Katerina Sukhomlin ${ }^{1}$, Vitaliy Koshirets ${ }^{2}$, Maria Zinchenko ${ }^{1}$, Oleksandr Zinchenko ${ }^{1}$, Yurii Biletskyi ${ }^{1}$}

${ }^{1}$ Lesja Ukrainka Eastern European National University, Lutsk, Ukraine

${ }^{2} \mathrm{SD}$ «Volyn Regional Phytosanitary Laboratory», Lutsk, Ukraine

Correspondence: suhomlinkb@gmail.com

Abstract. Diabrotica virgifera virgifera is a corn pest belonging to quarantine objects in Europe, so the condition of the western corn rootworm population requires continuous monitoring and control of its size and 
distribution. The conducted surveys results of their number and distribution in the territory of Volyn oblast in 2017-2018 are analyzed based on the information provided by the Volyn Regional Phytosanitary Laboratory. The monitoring was carried out by method of route surveys and using synthetic sex pheromones in corn crops. Nidi were detected using a ground-visual examination of corn plantings, in particular, using the examination of the root system and the leaf surface of the weakened corn plants. For the analysis of the western corn rootworm phytosanitary risk, we calculated the average weighted indexes of penetration probability, probability of acclimatization, potential economic harmfulness, probability of introduction and potential losses. In the Volyn region, this quarantine organism was first observed in 2017, and since then it has increased the area of lesion. Pest nidi are registered in 10 districts, 11 settlements on an area of 406,238 hectares. It was revealed that the largest areas of lesion (from 50 to 80 ha) were observed in Lutsk, Ivanychy, Ratne and Kovel districts. There were no registered nidi in Shatsksky, Lyubomlsky, Kamen-Kashirsky, Manevitsky, Kivertsivsky, Rozhischensky districts. The highest level of lesion was observed in the Lutsk region. The quantitative analysis of the acclimatization possibility and distribution of western corn rootworm has shown that the pest belongs to quarantine organisms and requires the use of all phytosanitary measures for containment and restriction of its distribution in the territory of the Volyn region. It has been established that within the region, climatic conditions and sufficient food supply are favourable for the development of $D$. virgifera virgifera, so the pest will not only survive, but also increase in number. The absence of natural barriers to restrict proliferation facilitates the expansion of the areal.

Key words: dynamics of distribution, quantitative analysis, probability of penetration, probability of acclimatization, potential economic harmfulness, probability of introduction, potential losses.

\section{Вступ}

Diabrotica virgifera virgifera LeConte, 1858 шкідник кукурудзи (Zea mays), який завдає значної шкоди корінню й призводить до втрат урожаю. Батьківщиною діабротики є Північна Америка, але сьогодні вид має Голарктичне поширення [1], віднесений до карантинних об'єктів у Європі [2].

Західного кукурудзяного жука $D$. virgifera virgifera вперше виявлено в липні 1992 року в м. Сурцині (Сербія) поблизу Міжнародного аеропорту Белград [1; 3]. Після ввезення в Європу D. virgifera virgifera поширився досить швидкими темпами в басейні Дунаю. Крім того, зараз повідомляють про декілька осередків поза Дунайським басейном. Попередні дослідження потенціалу відтворення D. virgifera virgifera, проведеного дослідниками ФАО для всієї Європи, показали, що цей шкідник, імовірно, виживе й розвинеться там, де в Свропі вирощують кукурудзу. Із моменту ввезення в Свропу D. virgifera virgifera значно поширився. У 1998 р. його виявлено поблизу аеропорту Венеції (Marco Polo) в Італії. у 2000 р. спіймано у двох нових аеропортах Італії та Швейцарії: у Мілані (Malpensa) й Лугано (Agno). У серпні 2001 p. перші екземпляри зібрано в Ростовській області Росії. Новий осередок виявлено у 2002 р. поблизу військового аеропорту Авіано у ФріуліВенеція-Джулія. У 2002 р. D. virgifera virgifera вперше знайдено у Франції неподалік аеропортів Руассі, Ле Бурже та Орлі (поблизу Парижа). У 2003 р. зареєстровано нові осередки у Франції (Ельзас), Бельгії, Нідерландах і Великобританії (знову ж таки біля міжнародних аеропортів). Це дало змогу Європейській та Середземноморській організаціями із карантину й захисту рослин (ЄОКЗР) зробити висновок, що основним шляхом розповсюдження $\epsilon$ авіаперевезення. У 2004 p. шкідник збільшує чисельність у країнах, де він був зареєстрований раніше [4]. У 2005 р. його вперше зафіксовано в Польщі. У 2007 p. - у Німеччині (Баден-Вюртемберг i Баварія). У 2009 р. шкідника вперше виловлено в Білорусі, поблизу кордонів із Польщею та Україною [5], а також на півночі Греції (префектури Салонік, Серрес, Флоріна й Пієрія). Наведена нижче карта (рис. 1) ілюструє ситуацію з D. virgifera virgifera в Свропі станом на 2012 р. у результаті обстежень, проведених Національною організацією 3 карантину та захисту рослин (НОКЗР). Підкреслимо, що економічні збитки спостерігали лише в Сербії, a також у деяких прикордонних районах Хорватії, Угорщини, Румунії й невеликих територій у Боснії та Герцеговині й Болгарії [6].

У Європі шкідника зареєстровано в Австрії, Болгарії, Боснії й Герцеговині, Великобританії, Угорщині, Німеччині, Греції, Італії, Польщі, Румунії, Сербії, Словаччині, Словенії, Україні, Франції, Хорватії, Чорногорії, Чехії, Швейцарії.

Основною кормовою рослиною личинок $\epsilon$ кукурудза. Личинки - вузькі олігофаги й здатні розвиватися лише на дуже обмеженій кількості інших злаків (наприклад Setaria verticilaria, S. glauca i Panicum miliaceum). Живлення корінням кукурудзи призводить до зменшення кореневої маси, поганого розвитку коріння та ураження гнилями, які надають йому бурого забарвлення. Ослаблені рослини стають сприйнятливішими до різних захворювань за 
Сучасний стан популяиї західного кукурудзяного жука Diabrotica virgifera virgifera (Coleoptera: Chrysomelidae) на території Волинської області

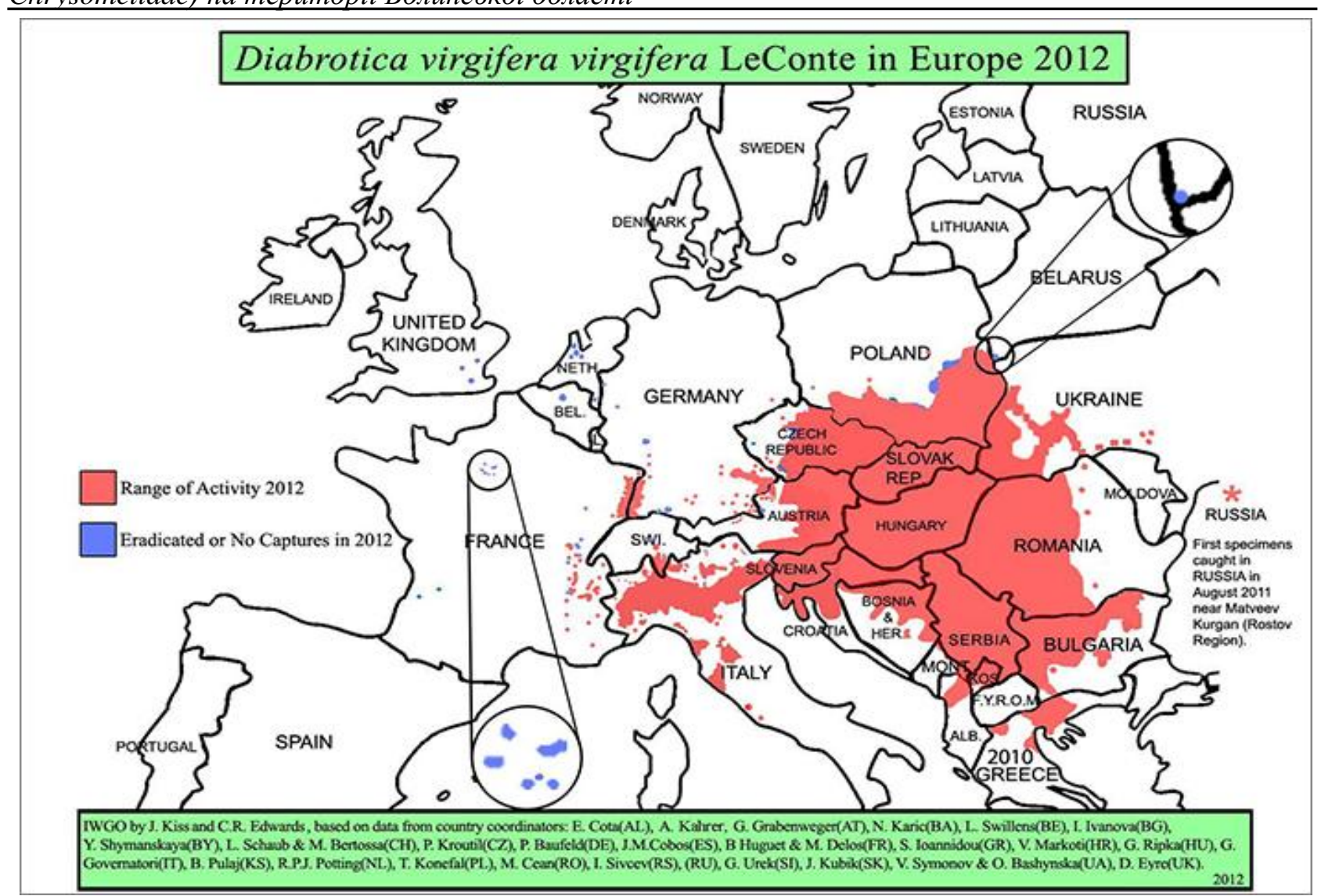

Рис. 1. Почирення у Свропі в 2012 р. (за даними СОКЗР [6])

рахунок того, що жуки й личинки є переносниками різноманітних збудників захворювань кукурудзи - грибкових, бактеріальних, вірусних. Пошкоджені дорослі рослини під час сильних вітрів і дощів легко полягають [1;7].

Імаго можуть харчуватися на злакових, айстрових, бобових, пасльонових, гарбузових й ін. Вони живляться пилком, маточковими стовпчиками, незрілими зернами, листям кукурудзи.

Симптомами ушкодження $є$ вилягання посівів кукурудзи через ураження кореневої системи личинками жука.

Карантинні організми стали активно проникати на територію нашої держави $[8 ; 9]$. Держспоживслужба підготувала підсумки щодо поширення карантинних хвороб, шкідників i бур'янів у 2018 р. [3].

Уперше в Україні цього шкідника зареєстровано у 2005 р. на Закарпатті. Спеціалісти карантинної служби за допомогою феромонних пасток відловили 22140 імаго самців та 297 імаго самок на присадибних ділянках, на полях господарств та в населених пунктах 13 районів Закарпатської області [7]. Виявлено осередки західного кукурудзяного жука в трьох нових гірських районах Закарпаття. Так, цього шкідника виявлено в усіх районах Закарпатської області, й територія під карантинним режимом щодо кукурудзяного жука збільшилася на 11373 га. На 1.01.2006 p. шкідника простежено в 13 районах, восьми містах і 452 населених пунктах Закарпатської області на площі 14148 га [10].

За результатами проведених обстежень щодо виявлення західного кукурудзяного жука за допомогою феромонних пасток (рис. 2) та візуально вперше в 2018 р. виявлено шкідника на території Київської (три райони), Кіровоградської (два райони), Миколаївської (один район), Одеської (сім районів) та Черкаської (три райони) областей, карантинний режим запроваджено на загальній площі 15394,85 га [1].

Також виявлено нові осередки шкідника й запроваджено карантинний режим у Вінницькій, Волинській, Житомирській, ІваноФранківській, Рівненській, Тернопільській та Хмельницькій областях. У цілому по Україні площа під карантинним режимом збільшилася на 19188,56 га.

Станом на 01.01.2019 р. шкідника помічено в 15 областях, 120 районах, 779 населених пунктах на загальній площі 108139,16 га [1]. У 2019 р. прогнозується збільшення площі в результаті виявлення нових осередків. Тому 

імені Лесі Украӥнки. Серія: Біологічні науки, 2019, 3 (387)

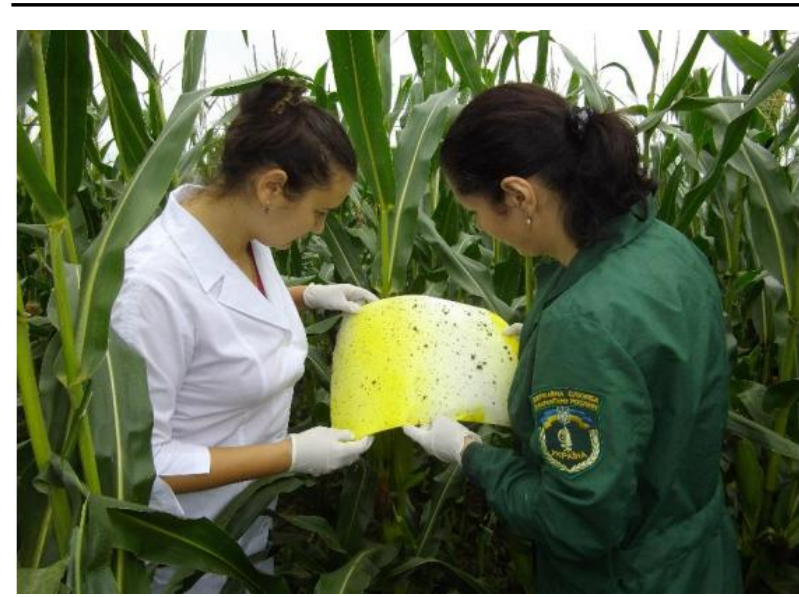

Рис. 2. Проведення обстежень на виявлення D. v. virgifera з використанням феромонних пасток (перевірка пастки) (фото Департаменту фітосанітарної безпеки [1])

потрібно здійснювати комплекс карантинних заходів щодо цього шкідника із застосуванням певних обмежень і дотриманням сівозмін (рекомендовано висівати багаторічні трави), у яких кукурудза поверталась би на своє місце не раніше ніж через три роки.

Мета дослідження - аналіз поширення та фітосанітарного стану території Волинської області щодо західного кукурудзяного жука.

\section{Матеріал та методи дослідження}

Матеріалом для дослідження були збори Державної установи «Волинська обласна фітосанітарна лабораторія», проведені у 2017 та 2018 р. на території всіх районів Волинської області, а також збори 2018 р., виконані співробітниками кафедри зоології Східноєвропейського національного університету імені Лесі Українки.

У 2017-2018 рр. моніторинг здійснювали методом маршрутних обстежень та за допомогою синтетичних статевих феромонів у посівах кукурудзи $[4 ; 11]$. Феромонні пастки панельного типу встановлювали в посівах на рослині на рівні качана 3 розрахунку одна пастка на 5 га. Розміщення пасток на полі - по периметру, заглиблюючись на 7-10 м у посіви. Огляд пасток державні інспектори з карантину рослин провадили кожної декади, із вибіркою комах на фільтрувальний папір. Види комах розпізнавали за допомогою визначників [12]. Через п'ять тижнів, після закінчення терміну дії феромону, його заміняли, а клейову поверхню пастки оновлювали.

Осередки захворювання виявляли за допомогою наземно-візуального обстеження посадок кукурудзи, зокрема огляду кореневої системи й листкової поверхні ослаблених рослин кукурудзи. При цьому враховували, що відставання рослин у розвитку, їх пожовтіння, вилягання можуть спричинити й інші численні шкідники кукурудзи.

Яйця виявляли методом флотації та подальшого перегляду під стереомікроскопом МБС 10 під час аналізу грунтових зразків, узятих на відстані близько 10 см від основи рослини; личинок виявляли в грунті в місцях зростання ушкоджених, пожовклих рослин із травня до початку серпня; жуків виявляли 3 кінця червня до середини жовтня візуально на рослинах кукурудзи, звертаючи особливу увагу на волоті, кукурудзяні стовпчики, качани молочно-воскової стиглості, пазухи листя, стебла. Крім того, пошук імаго проводили й на рослинах поблизу поля з кукурудзою.

Diabrotica virgifera відрізняється від близького виду Diabrotica barberi чорними або світлими 3 чорним зовнішнім краєм (а не зеленими) стегнами, а також будовою едеагуса самця та сперматеки самки. Личинка Diabrotica virgifera відрізняється від личинок близьких видів будовою головної капсули й анальних сегментів черевця [12].

Для кількісного аналізу ризику проникнення та поширення західного кукурудзяного жука на території Волинської області використано схему проведення аналізу фітосанітарного ризику (АФР) за I. М. Смітом й А. Д. Орлінським [13; 14]. Розрахунок середньозважених показників вірогідності проникнення (ВП), акліматизації (ВА), потенційної економічної шкодочинності (ПЕШ), вірогідність інтродукції (BI) та потенційних утрат (ПВ) здійснювали за формулами:

$$
\begin{gathered}
\mathrm{B \Pi}=\left[\sum_{i=1}^{n} a_{i} w_{i}\right] / \sum_{i=1}^{n}, \\
\mathrm{BA}=\left[\sum_{i=1}^{n} a_{i} w_{i}\right] / \sum_{i=1}^{n}, \\
\Pi Е Ш=\left[\sum_{i=1}^{n} a_{i} w_{i}\right] / \sum_{i=1}^{n},
\end{gathered}
$$

де $w_{i}$ - коефіцієнт питання, $a_{i}$ - оцінка в балах.

$$
\begin{gathered}
\text { ВІ }=\text { ВП } \times \text { ВА } / 100, \\
\Pi \mathrm{B}=\mathrm{B} \Pi \times \mathrm{BA} \times \text { ПЕШ } / 100 .
\end{gathered}
$$

\section{Аналіз результатів дослідження}

Уперше на Волині D. virgifera virgifera відзначено у 2017 р. на території Турійського (Розпорядження Турійської районної державної адміністрації від 18.08.2017 p. № 202), Старовижівського (Розпорядження Старовижівської районної державної адміністрації від 19.08.2017 p. № 339), Ратнівського (Розпорядження Ратнівської районної державної 
Сучасний стан популящї західного кукурудзяного жука Diabrotica virgifera virgifera (Coleoptera: Chrysomelidae) на території Волинської області

адміністрації від 19.08.2017 р. № 217), Ковельського (Розпорядження Ковельської районної державної адміністрації від 22.08.2017 p. № 267), Володимир-Волинського (Розпорядження Володимир-Волинської районної державної адміністрації від 28.09.2017 р. № 343), Іваничівського (Розпорядження Іваничівської районної державної адміністрації від 29.09.2017 p. № 319) та Луцького (Розпорядження Луцької районної державної адміністрації від 20.10.2017 p. № 539) районів. Загальна площа ураження становила 330 га. У 2018 р. шкідника зареєстровано на території Локачинського (Розпорядження Локачинської районної державної адміністрації від 02.08.2018 p. № 315), Горохівського (Розпорядження Горохівської районної державної адміністрації від 20.08.2018 р. № 258) і Любешівського (Розпорядження Любешівської районної державної адміністрації від 13.09.2018 р. № 307) районів. Сьогодні, за повідомленням ДУ «Волинська обласна фітосанітарна лабора-торія», осередки цього шкідника зареєстровано в 10 районах, 11 населених пунктах на площі 406,238 га (табл. 1). Найбільші площі зараження відзначено в Луцькому, Івани-чівському, Ратнівському та Ковельському районах. Відсутні осередки в Шацькому, Любомльському, КаміньКаширському, Мане-вицькому, Ківерцівському, Рожищенському районах.

У результаті опрацювання річних звітів ДУ «Волинська обласна фітосанітарна лабораторія» проаналізували динаміку поширення західного кукурудзяного жука (рис. 1) за останні два роки та встановили його поширення.

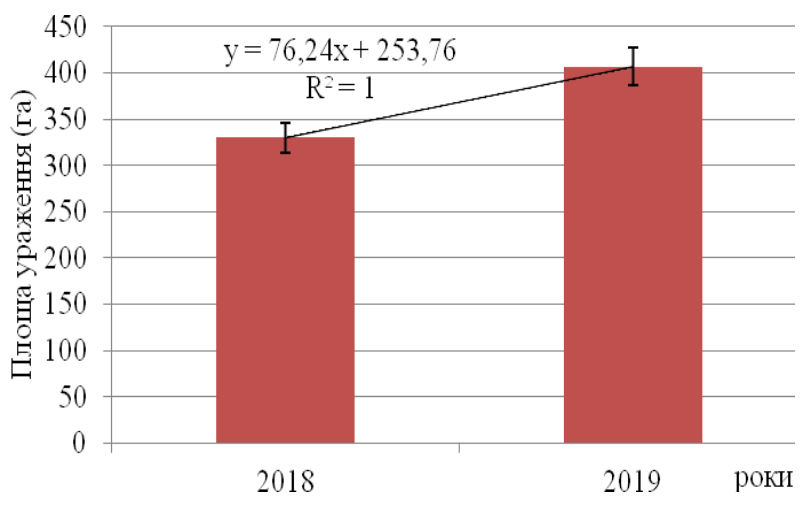

Рис. 1. Динаміка поширення західного

кукурудзяного жука у Волинській області за 2008-2018 рр. (площяа, га), — - лінійна лінія тренду

За два роки, коли шкідника реєстрували в межах області, відзначено збільшення площ ураження у Волинській області на 76,24 га. Лінійна лінія тренду також підтверджує тенденцію до збільшення площ області, заселених цим небезпечним шкідником. Величина достовірності апроксимації становить 1,0 . Тому згладжування можна вважати достовірним, хоча потрібно зважити на малу (дворічну) вибірку, оскільки паразита раніше не помічали в межах області.

Для загальної оцінки рівня ризику поширення діабротики у Волинській області, насамперед, оцінювали вірогідність проникнення шкідника та можливість його

\section{Поширення західного кукурудзяного жука Diabrotica virgifera virgifera у Волинській області}

\begin{tabular}{|c|c|c|c|c|c|c|c|}
\hline \multirow[b]{2}{*}{$\begin{array}{l}\text { № } \\
\text { 3/II }\end{array}$} & \multirow[b]{2}{*}{$\begin{array}{c}\text { Адміністративний } \\
\text { район області }\end{array}$} & \multicolumn{3}{|c|}{ Заражено } & \multicolumn{3}{|c|}{ Площа зараження, га } \\
\hline & & $\begin{array}{c}\text { міст } \\
\text { і населених } \\
\text { пунктів }\end{array}$ & $\begin{array}{l}\text { приса- } \\
\text { дибних } \\
\text { ділянок }\end{array}$ & $\begin{array}{c}\text { госпо- } \\
\text { дарств } \\
\text { всіх форм } \\
\text { власноті }\end{array}$ & $\begin{array}{l}\text { приса- } \\
\text { дибних } \\
\text { ділянок }\end{array}$ & $\begin{array}{c}\text { госпо- } \\
\text { дарств } \\
\text { всіх форм } \\
\text { власноті }\end{array}$ & разом \\
\hline 1 & Турійський & 1 & 0 & 1 & 0,00 & 30,00 & 30,00 \\
\hline 2 & Старовижівський & 1 & 0 & 1 & 0,00 & 20,00 & 20,00 \\
\hline 3 & Ратнівський & 2 & 1 & 1 & 5,00 & 45,00 & 50,00 \\
\hline 4 & Ковельський & 1 & 0 & 1 & 0,00 & 50,00 & 50,00 \\
\hline 5 & $\begin{array}{l}\text { Володимир- } \\
\text { Волинський }\end{array}$ & 1 & 0 & 1 & 0,00 & 45,00 & 45,00 \\
\hline 6 & Іваничівський & 1 & 0 & 1 & 0,00 & 60,00 & 60,00 \\
\hline 7 & Локачинський & 1 & 0 & 1 & 0,00 & 23,94 & 23,94 \\
\hline 8 & Горохівський & 1 & 0 & 1 & 0,00 & 47,00 & 47,00 \\
\hline 9 & Луцький & 1 & 0 & 1 & 0,00 & 80,00 & 80,00 \\
\hline 10 & Любешівський & 1 & 1 & 0 & 0,30 & 0,00 & 0,298 \\
\hline & Разом & 11 & 2 & 9 & 5,30 & 400,94 & 406,238 \\
\hline
\end{tabular}


Науковий вісник Східноєвропейського національного університету імені Лесі Українки. Серія: Біологічні науки, 2019, 3 (387)

Таблиия 2

Кількісна оцінка фітосанітарного ризику щодо західного кукурудзяного жука у Волинській області

\begin{tabular}{|c|c|c|c|c|c|c|c|c|c|c|c|}
\hline \multicolumn{4}{|c|}{ Вірогідність проникнення (ВП) } & \multicolumn{4}{|c|}{ Вірогідність акліматизації (ВА) } & \multicolumn{4}{|c|}{$\begin{array}{c}\text { Потенційна економічна шкодо- } \\
\text { чинність (ПЕШ) }\end{array}$} \\
\hline $\begin{array}{c}\text { номер } \\
\text { питання } \\
\text { в схемі }\end{array}$ & $\begin{array}{c}\text { коефі- } \\
\text { ціснт } \\
\text { питання } \\
\text { (wi) } \\
\end{array}$ & $\begin{array}{l}\text { оцін- } \\
\text { ка, } \\
\text { балів } \\
\text { (ai) }\end{array}$ & $\begin{array}{l}\text { wi } \\
* a i\end{array}$ & $\begin{array}{c}\text { номер } \\
\text { питання } \\
\text { в схемі }\end{array}$ & $\begin{array}{c}\text { коефі- } \\
\text { ціснт } \\
\text { питання } \\
(w i) \\
\end{array}$ & $\begin{array}{l}\text { оцін- } \\
\text { ка, } \\
\text { балів } \\
\text { (аі) }\end{array}$ & $\begin{array}{l}\text { wi } \\
*^{*} a i\end{array}$ & $\begin{array}{c}\text { номер } \\
\text { питання } \\
\text { в схемі }\end{array}$ & $\begin{array}{c}\text { коефі- } \\
\text { ціснт } \\
\text { питання } \\
\text { (wi) } \\
\end{array}$ & $\begin{array}{l}\text { оцін- } \\
\text { ка, } \\
\text { балів } \\
\text { (аi) }\end{array}$ & $\begin{array}{c}w^{*}{ }^{*} \\
a i\end{array}$ \\
\hline 1,1 & 6 & 2 & 12 & 1,14 & 4 & 2 & 8 & 2,1 & 9 & 7 & 63 \\
\hline $1,3 \mathrm{~b}$ & 8 & 1 & 8 & 1,15 & 8 & 7 & 56 & 2,2 & 5 & 1 & 5 \\
\hline 1,4 & 7 & 1 & 7 & 1,19 & 9 & 4 & 36 & 2,3 & 7 & 5 & 35 \\
\hline $1,5 \mathrm{~b}$ & 8 & 7 & 56 & 1,2 & 8 & 7 & 56 & 2,4 & 5 & 5 & 25 \\
\hline 1,6 & 8 & 9 & 72 & 1,21 & 6 & 7 & 42 & 2,5 & 6 & 6 & 36 \\
\hline $1,7 \mathrm{~b}$ & 6 & 7 & 42 & 1,22 & 2 & 6 & 12 & 2,6 & 8 & 7 & 56 \\
\hline 1,8 & 2 & 1 & 2 & 1,23 & 1 & 9 & 9 & 2,7 & 7 & 8 & 56 \\
\hline 1,9 & 6 & 9 & 54 & 1,24 & 8 & 9 & 72 & 2,8 & 8 & 6 & 48 \\
\hline 1,1 & 5 & 1 & 5 & 1,25 & 5 & 8 & 40 & 2,9 & 6 & 5 & 30 \\
\hline 1,11 & 6 & 9 & 54 & 1,26 & 9 & 5 & 45 & 2,1 & 4 & 5 & 20 \\
\hline $1,12 \mathrm{~b}$ & 8 & 4 & 32 & 1,27 & 8 & 7 & 56 & 2,11 & 2 & 1 & 2 \\
\hline \multirow[t]{8}{*}{1,13} & 6 & 5 & 30 & 1,28 & 5 & 8 & 40 & 2,12 & 4 & 5 & 20 \\
\hline & & & & 1,29 & 5 & 5 & 25 & 2,13 & 6 & 1 & 6 \\
\hline & & & & 1,3 & 8 & 6 & 48 & 2,14 & 6 & 5 & 30 \\
\hline & & & & & & & & 2,15 & 5 & 8 & 40 \\
\hline & & & & & & & & 2,16 & 6 & 4 & 24 \\
\hline & & & & & & & & 2,17 & 5 & 2 & 10 \\
\hline & & & & & & & & 2,18 & 6 & 7 & 42 \\
\hline & & & & & & & & 2,19 & 5 & 6 & 30 \\
\hline$\sum$ & 76 & & $\begin{array}{c}37 \\
4\end{array}$ & & 86 & & $\begin{array}{c}54 \\
5\end{array}$ & & 110 & & 578 \\
\hline \multicolumn{4}{|c|}{ ВП $=4,921053$} & & $\mathrm{BA}=6,3372$ & & & \multicolumn{4}{|c|}{ ПЕШ $=5,254545$} \\
\hline
\end{tabular}

акліматизації, потім - економічні втрати у випадку його акліматизації [3]. Згідно 3 проведеним аналізом фітосанітарного ризику західного кукурудзяного жука одержано дані, які потрібні для математичного підтвердження можливості, проникнення, акліматизації й поширення D. virgifera virgifera. Розрахунок середньозважених показників вірогідності поширення (ВП), акліматизації (ВА), потенційної економічної шкодочинності (ПЕШ) показав такі результати (табл. 2). Розрахунок середньозважених показників вірогідність інтродукції (BI) та потенційних утрат засвідчив такі результати: (ПВ), $\mathrm{BI}=0,311857$, а ПВ=1,638669.

Поділ на карантинні й некарантинні види визначає показник ПВ, який дорівнює 1,4 $[3 ; 13]$. Для західного кукурудзяного жука величина показника $\Pi \mathrm{B}=1,64$, що й підтверджує віднесення цього шкідника до карантинних організмів із застосуванням усіх фітосанітарних заходів щодо стримування та обмеження його поширення територією Волинської області.

Крім того, потрібно враховувати, що розповсюдження й адаптація діабротики залежать від температурних умов регіону. Для визначення можливості адаптації та розповсюдження західного кукурудзяного жука у Волинській області ми проаналізували температурні умови за останні два роки (табл. 3).

Аналіз температурних показників свідчить, що середньорічні температури останніх двох років коливаються від 9,0 до $9,4^{\circ} \mathrm{C}$ і сприяють адаптації й поширенню шкідника всією територією області. Середньомісячні температури липня-серпня двох останніх років, тобто періоду масового льоту імаго діабротики, становили $19,5-20,2^{\circ} \mathrm{C}$, мали позитивний вплив на поширення західного кукурудзяного жука, оскільки, за даними [15], найбільш активне поширення шкідника відбувається за середньомісячних температур повітря $18-26^{\circ} \mathrm{C}$ iз середини липня до початку вересня. Зимові температури Волинської області перебувають у межах $-3,0-+1,1^{\circ} \mathrm{C}$ і сприяють зимівлі яєць шкідника.

\section{Обговорення}

У період дослідження під час проведення обстежень зі встановлення фітосанітарного 
Сучасний стан популяиії західного кукурудзяного жука Diabrotica virgifera virgifera (Coleoptera: Chrysomelidae) на території Волинської області

Табличя 3

Метеорологічні показники Волинської області (2017-2018рр.)

\begin{tabular}{|c|c|c|c|c|c|c|c|c|c|c|c|c|c|}
\hline \multirow{2}{*}{ 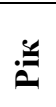 } & \multicolumn{12}{|c|}{ Середньомісячні температурні показники } & \multirow[b]{2}{*}{$\mathbf{m}$} \\
\hline & 01 & 02 & 03 & 04 & 05 & 06 & 07 & 08 & 09 & 10 & 11 & 12 & \\
\hline 홍 & $-5,2$ & $-1,7$ & $+6,2$ & $+7,9$ & $+14,3$ & $+18,7$ & $+18,9$ & $+19,9$ & $+13,9$ & $+9,0$ & $+3,4$ & $+2,1$ & 9,0 \\
\hline$\stackrel{\infty}{\stackrel{i}{i}}$ & $-0,7$ & $-3,7$ & $-0,6$ & $+13,5$ & $+17,5$ & $+18,8$ & $+20,0$ & $+20,5$ & $+15,4$ & $+9,5$ & $+2,7$ & $+0,1$ & 9,4 \\
\hline $\mathrm{m}$ & $-3,0$ & $-2,7$ & 2,8 & 10,7 & 15,9 & 18,8 & 19,5 & 20,2 & 14,7 & 9,3 & 3,1 & 1,1 & 9,2 \\
\hline
\end{tabular}

стану області виявлено нові осередки карантинного організму - західного кукурудзяного жука - на площі 76,238 га. Найвищий рівень ураження (рис. 2) простежено в Луцькому районі (80 га), а найнижчий - у Любешівському $(0,3$ га).

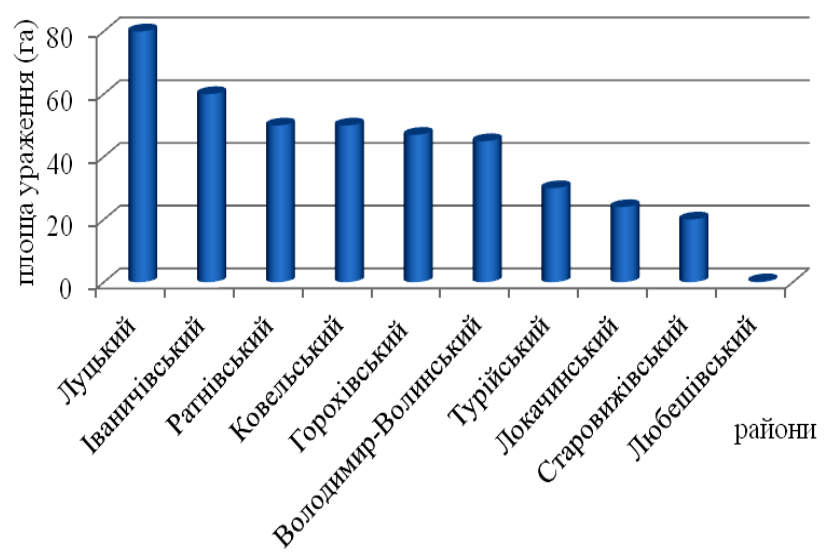

Рис. 2. Площа ураження Diabrotica virgifera virgifera у районах Волинської області

Запроваджено карантинний режим у таких районах, як Локачинський (на площі 23,94 га), Розпорядження Локачинської районної державної адміністрації від 08 серпня 2018 р. № 315; Ратнівський (на площі 5 га), Розпорядження Ратнівської державної адміністрації від 16 серпня 2018 p. № 286; Горохівський (на площі 47 га); Розпорядження Горохівської районної державної адміністрації від 20 серпня 2018 p. № 258; Любешівський на площі 0,298 га; Розпорядження Любешівської районної державної адміністрації від 13 вересня 2018 p. № 307.

У межах Волинської області кліматичні умови для розвитку D. virgifera virgifera сприйнятливі $[1 ; 3 ; 8 ; 16]$, кормова база наявна, природні бар'єри відсутні, а тому діабротика буде не лише виживати, а й розширювати свій ареал.

Виявлення D. virgifera virgifera на території Волинської області потребує застосування необхідних заходів із ліквідації осередків, згідно 3 наявним фітосанітарним законодавством $[4 ; 9 ; 11 ; 17]$. Для цього передбачено запобіжні, організаційні, агротехнічні, біологічні, хімічні заходи, а також використання стійких сортів.

Ефективним агротехнічним заходом проти D. virgifera virgifera $є$ сівозміна, що включає зернові, крім кукурудзи, багаторічні трави, конюшину, люцерну тощо. Поля кукурудзи, на яких виявлено осередки, переорюють після збирання врожаю й наступного року засівають іншими культурами. На цих полях заборонено висівання кукурудзи протягом трьох років. По периферії висівають стійкі сорти та гібриди, яким властиві регенеративна здатність швидко відновлювати коріння й глибоке їх залягання. В усіх вітчизняних та світових літературних джерелах $[2 ; 4 ; 9 ; 11 ; 17]$ сівозміну згадують як найбільш ефективний захід контролю цього шкідника. Однак лише сівозміна впливає на зменшення кількості шкідників і втрати врожаю. Вона не унеможливить пошкодження, оскільки життєвий цикл може бути завершений на інших рослинах-хазяях. Дорослі можуть швидко й широко розповсюджуватися (до 100 км на рік), самки дуже плодючі та невелика частина яєць може затримати свій розвиток на один рік.

Проти личинок або дорослих комах у світі досить широко застосовують хімічні заходи. Відповідно до сучасного Переліку пестицидів й агрохімікатів, дозволених до використання в Україні [18], проти західного кукурудзяного жука можна застосовувати такі препарати: Кайзо, ВГ (лямбда-цигалотрон, 50 г/л) - 
обприскування рослин у період вегетації (одна обробка) в розрахунку 0,3 кг/га; Карате Зеон 050 CS, СК (лямбда-цигалотрон, 50 г/л) обприскування рослин у період вегетації (дві обробки) в розрахунку 0,3 л/га; Регент $20 \mathrm{G}$, г (фіпроніл, 20 г/кг) - унесення 3 подальшим загортанням у грунт перед посівом у розрахунку 10 кг/га.

Використання трансгенних стійких сортів кукурудзи в Європейському Союзі проти D. virgifera virgifera не врегулювано. Селекція природної стійкості кукурудзи до діабротики проводять у США [19] та Західній Свропі [20].

\section{Висновки}

За роки поширення діабротики в межах Волинської області осередки цього шкідника зареєстровано в 10 районах, 11 населених пунктах на площі 406,238 га. Найбільші площі зараження (50-80 га) відзначено в Луцькому, Іваничівському, Ратнівському й Ковельському районах. Не помічено осередків у Шацькому, Любомльському, Камінь-Каширському, Маневицькому, Ківерцівському, Рожищенському районах.

Проведений кількісний аналіз можливості акліматизації та поширення західного кукурудзяного жука засвідчив, що шкідник належить до карантинних організмів і потребує застосування всіх фітосанітарних заходів щодо стримування й обмеження його поширення територією Волинської області. Установлено, що температурні умови сприяють адаптації та поширенню діабротики в межах області, тому шкідник не лише виживатиме, а й примножуватиме свою чисельність.

\section{Література}

1. Західний кукурудзяний жук (Diabrotica virgifera virgifera Le Conte) - небезпека для вітчизняних виробників кукурудзи. Департамент фітосанітарної безпеки, контролю в сфері насінництва та розсадництва Держпродспоживслужби 12.11.2018. URL: http://www. consumer.gov.ua/Pictures/Files/Editor/document/фіто/к арантинні\%20організми/Західний\%20кукурудзяний \%20жук.pdf (дата звернення Бер 236 2019).

2. Smith, I. M.; McNamara, D. G.; Scott, P. R.; Holderness, M. Quarantine pests for Europe. Second Edition. Data sheets on quarantine pests for the European Union and for the European and Mediterranean Plant Protection Organization. CAB International: Wallingford, $1997 . \quad$ URL: https://doi.org/10.1017/S0007485300041675

3. Андреянова, Н. І.; Сікура, О. А. Ризик проникнення та розповсюдження Diabrotica virgifera virgifera Le Conte у вільні від шкідника регіони України. Науковий вісник Ужгородського університету. Серія Біологія, 2010, 29, сс 167-169.

4. Пилипенко, Л. А.; Константинова, Н. А. Фитосанитарный контроль западного кукурузного жука в странах ЕС и в Украине. Защита и карантин растений, 2009, 7, сс 29-33.

5. Трепашко, Л. И.; Голунов, И. А.; Надточаева, C. В. Западный кукурузный жук обнаружен в Беларуси. Защцита и карантин растений. 2010, 2, сс 42.

6. Situation of Diabrotica virgifera virgifera in the EPPO region (2012). European and Mediterranean Plant Protection Organization. URL: https://www.eppo.int/ACTIVITIES/plant_quarantine/sh ortnotes_qps/diabrotica_virgifera

7. Сікура, О. А. Західний кукурудзяний жук: особливості розповсюдження Diabrotica virgifera virgifera Le Conte в Закарпатті, динаміка заселення території та посівів кукурудзи. Карантин $i$ захист рослин, 2010, 11, pp 12-17.

8. Мовчан, О. М. Карантинні шкідливі організми. Частина 1. Карантинні шкідники. Світ: Київ, 2002.

9. Про затвердження переліку регульованих шкідливих організмів. Наказ Міністерства Аграрної політики України № 467 vid 04.08.2010. URL: https://www.zakon inormativ.info/index.php?option= com_lica\&p $=0 \&$ base $=1 \&$ menu $=448175 \& u=1 \&$ type $=1$ \&view=text.

10. Огляд розповсюдження карантинних організмів в Україні на 1 січня 2019. URL: http://www.consumer.gov.ua/ContentPages/Oglyad Pos hirennya_Karantinnikh_Organizmiv_V_Ukraini/219/

11. Ющук, Т. Д.; Мельник, П. О. Методичні вказівки по виявленню кукурудзяного кореневого жука та заходи боротьби. Чернівці, 2006.

12. Krysan, J. L. Introduction: Biology, Distribution, and Identification of Pest Diabrotica. In Methods for the Study of Pest Diabrotica; Krysan, J. L., Miller, T. A., Eds. Springer-Verlag: New York, 1986, pp. 1-23. DOI: 10.1007/978-1-4612-4868-2_1

13. Орлинский, А. Д. Концепция количественной оценки фитосанитарного риска. Агро ХХI. 2006, 7-9, сс 15-19.

14. Смит, И. М.; Орлинский, А. Д. Международная терминология по карантину растений. Защчита и карантин растений. 1997, 12, cc 21-28.

15. Edwards, C.; Bledsoe, L.; Obermeyer, J. The dramatic shift of western corn rootworm Diabrotica virgifera virgifera Le Conte (Coleoptera: Chrysomelidae) to maize in rotation with soybeans in Indiana. In 20 Inter. congr. Entomol., Firenze, Italy, Aug. 25-31, 1996; Proc: Firenze, 1996; pp 469.

16. Мовчан, О. М.; Сикало, О. О.; Мельник П. О.; Сирбу, Р. Д. Поширення діабротики в Україні. Карантин $і$ захист рослин. 2006, 7, pp 24-25.

17. Oleson, J. D.; Park, Y. L.; Nowatzki, T. M.; Tollefson, J. J. Node-injury scale to evaluate root injury by corn rootworms (Coleoptera: Chrysomelidae). J. Econ. Entomol. 2005, 98 (1), pp 1-8. 
Сучасний стан популяиї західного кукурудзяного жука Diabrotica virgifera virgifera (Coleoptera: Chrysomelidae) на території Волинської області

18. Державний реєстр пестицидів i агрохімікатів, дозволених до використання в Україні в 2017 році, затверджений Міністерством екології та природних ресурсів України від 08.04.2017. URL: https://menr.gov.ua/content/derzhavniy-reestrpesticidiv-i-agrohimikativ-dozvolenih-do-vikoristannyav-ukraini-dopovnennya-z-01012017-zgidno-vimogpostanovi-kabinetu-ministriv-ukraini-vid-21112007-1328.html
19. Tollefson, J. J; Evaluating maize for resistance to Diabrotica virgifera virgifera LeConte (Coleoptera: Chrysomelidae). Maydica. 2007, 52(3), pp 311-318.

20. Ivezić, M; Raspudić, E; Brmez, M; Majic, I; Brkić, I; Tollefson, J. J; Bohn, M; Hibbard, B. E; Šimić D. A review of resistance breeding options targeting western corn rootworm (Diabrotica virgifera virgifera LeConte). Agricultural and Forest Entomology. 2009, 11(3), pp 307-11. DOI: $10.1111 / \mathrm{j} .1461-$ 9563.2009.00434.x 